College of Science and Technology, during the academic year 1935-36: Extensions of fellowships already satisfactorily held for one year to :-Dr. J. Bell, for research in fuel technology-"A spectrographic investigation of hydrocarbon combustion"; Dr. H. I. Stonehill, for research in chemistry - "The applicability of the modern theories of strong electrolytes due to Debye, La Mer, Bjerrum, Davies, etc., and the measurement of the E.M.F. of certain cells"; and Mr. J. R. Tillman, for research in physics on "Electron diffraction". New fellowships for one year, renewable for a second year, to :-Mr. R. Walls, of the University of Liverpool, for an investigation of the metamorphic rocks of north-east Scotland, under Prof. P. G. H. Boswell ; Mr. E. W. Hewson, of the Mount Allison University, Sackville, Canada, and the University of Toronto, for research in meteorology, more especially the detailed structure of discontinuities between air masses as occurring in England and Canada, under Prof. D. Brunt; Mr. J. E. Carruthers, of Emmanuel College, Cambridge, for the study of primary photochemical processes and oxidation, applied to kinetics of gas reactions in general, under Prof. W. A. Bone.

\section{The Sky in August}

Mercury passes through superior conjunction on August 10, after which date the planet is once more an evening object. Venus attains its greatest brilliance on August 3, the stellar magnitude then being $-4 \cdot 2$. The planet is now moving towards the sun, and will be difficult to pick up with the naked eye at the end of the month. Mars is still conspicuous in the evening sky, but is decreasing in brilliance, from $+0 \cdot 6^{\mathrm{m}}$ to $+0 \cdot 8^{\mathrm{m}}$ during the month. This planet is moving towards Jupiter, and will be in conjunction with it on August 27 at $23 \mathrm{~h}$., Mars being $2 \cdot 2^{\circ} \mathrm{S}$. Jupiter is much the brighter of the two, its stellar magnitude declining from $-1 \cdot 7^{\mathrm{m}}$ to $-1 \cdot 5^{\mathrm{m}}$ during August. Saturn is now rising before midnight, and will be in opposition to the sun on August 31. The stellar magnitude declines from $-0.02^{\mathrm{m}}$ at the beginning of the month to $0.00^{\mathrm{m}}$ at the end of the month. It is interesting to inquire whether there is any prospect of seeing all five of the naked-eye planets this year. Venus and Saturn make their closest approach in Right Ascension on August 18, when the two planets are $11 \mathrm{~h} .16 \mathrm{~m} .37 \mathrm{~s}$. apart. On account of their southerly declinations, they will not be simultaneously visible at Greenwich, or at any station north of terrestrial latitude $39^{\circ} \mathrm{N}$. Observers at stations south of this limit will be able to see four of the five naked-eye planets at the same time. Venus goes off as Mercury comes on, but it may be possible to pick out both Mercury and Venus in the sunset at a southern station just after Saturn has risen, the best chance of success being right at the end of the month.

\section{Announcements}

Ir is announced in Science that Dr. R. H. Fowler, Plummer professor of mathematical physics in the University of Cambridge, has been appointed visiting lecturer in mathematics at Princeton University for the second term of next year.
The annual autumn meeting of the Institute of Metals will be held in Newcastle-upon-Tyne on September 9-12, under the chairmanship of Dr. Harold Moore, president of the Institute. The Autumn Lecture will be delivered on September 9 by Dr. H. W. Brownsdon, who will take as his subject "Metal Melting-Its Effect on Quality"; the lecture will be followed by a discussion. Further information can be obtained from the Secretary, Institute of Metals, 36 Victoria Street, London, S.W.1.

A SPECIAL train has recently been organised in Germany for the rapid conveyance of first aid to any place where a great disaster such as a flood or earthquake has taken place.

Erratum. Prof. Hans Falkenhagen writes, in reference to the letter in NATURE of May 18, p. 830, entitled "Compressibility of Electrolytic Solutions", by Ch. Bachem and himself, that the expression $k=A c+B c^{3 / 2}$, as written by them, is incorrect. It should read $k=C+A c+B c^{3 / 2}$.

Applications are invited for the following appointments, on or before the dates mentioned:

A technical officer at the Royal Aircraft Establishment, South Farnborough, Hants, to assist in the investigation of aircraft problems relating to aerodynamics, strength and stiffness-Chief Superintendent, Royal Aircraft Establishment, South Farnborough, Hants, quoting A. 734 (July 29).

An assistant (Grade II) at the Building Research Station for work on problems connected with painting and decoration-Establishment Officer, Department of Scientific and Industrial Research, 16 Old Queen Street, London, S.W.1 (July 31).

A lecturer in mathematics with subsidiary biology at the Saltley Church of England Training College for Schoolmasters, Birmingham-The Principal (Aug. 1).

An engineer officer for the Indian Mercantile Marine Cadets Training Ship Dufferin-High Commissioner for India, General Department, India House, Aldwych, London, W.C.2 (Aug. 1).

An assistant lecturer in inorganic and physical chemistry, University College of the South West, Exeter-The Registrar (Aug. 5).

A full-time and a part-time graduate assistant in the Department of Mechanical Engineering, Guildford Technical College-Director and Secretary, Technical College, Park Street, Guildford.

Part-time lecturers in automobile engineering, drawing and design, and workshop processes in the Mechanical Engineering Department, The Polytechnic, Regent Street, London, W.1-Director of Education.

An assistant lecturer in civil engineering in the Battersea Polytechnic, London, S.W.11-The Principal.

A lecturer in plant pathology and zoology at the Swanley Horticultural College for Women, Swanley, Kent-The Principal. 